\title{
Screening of thermotolerant and thermophilic fungi aiming $\beta$-xylosidase and arabinanase production
}

\author{
Vivian Machado Benassi ${ }^{1}$, Rosymar Coutinho de Lucas ${ }^{1}$, João Atílio Jorge ${ }^{2}$, \\ Maria de Lourdes Teixeira de Moraes Polizeli ${ }^{2}$ \\ ${ }^{1}$ Departamento de Bioquímica e Imunologia, Faculdade de Medicina de Ribeirão Preto, \\ Universidade de São Paulo, Ribeirão Preto, SP, Brazil. \\ ${ }^{2}$ Departamento de Biologia, Faculdade de Filosofia, Ciências e Letras de Ribeirão Preto, \\ Universidade de São Paulo, Ribeirão Preto, SP, Brazil.
}

Submitted: August 17, 2012; Approved: April 17, 2014

\begin{abstract}
Plant cell wall is mainly composed by cellulose, hemicellulose and lignin. The heterogeneous structure and composition of the hemicellulose are key impediments to its depolymerization and subsequent use in fermentation processes. Thus, this study aimed to perform a screening of thermophilic and thermotolerant filamentous fungi collected from different regions of the São Paulo state, and analyze the production of $\beta$-xylosidase and arabinanase at different temperatures. These enzymes are important to cell wall degradation and synthesis of end products as xylose and arabinose, respectively, which are significant sugars to fermentation and ethanol production. A total of 12 fungal species were analyzed and 9 of them grew at $45^{\circ} \mathrm{C}$, suggesting a thermophilic or thermotolerant character. Additionally Aspergillus thermomutatus anamorph of Neosartorya and A. parasiticus grew at $50{ }^{\circ} \mathrm{C}$. Aspergillus niger and Aspergillus thermomutatus were the filamentous fungi with the most expressive production of $\beta$-xylosidase and arabinanase, respectively. In general for most of the tested microorganisms, $\beta$-xylosidase and arabinanase activities from mycelial extract (intracellular form) were higher in cultures grown at high temperatures $\left(35-40^{\circ} \mathrm{C}\right)$, while the correspondent extracellular activities were favorably secreted from cultures at $30^{\circ} \mathrm{C}$. This study contributes to catalogue isolated fungi of the state of São Paulo, and these findings could be promising sources for thermophilic and thermotolerant microorganisms, which are industrially important due to their enzymes.
\end{abstract}

Key words: screening, $\beta$-D-xylosidase, arabinanase, thermotolerant, thermophilic.

\section{Introduction}

The plant cell wall polysaccharides biodegradation is an important biotechnological process for obtaining monosaccharides which are useful in different industrial processes, such as fermentation for the generation of bioethanol, and biological activities including antioxidant activity, blood and skin related effects, anti-allergy, antiinfection, anti-inflammatory properties and selective cytotoxic activities (Chapla et al., 2012; Ranaval et al., 2010).

The plant cell wall lignocelulolytic biomass is mainly composed by cellulose (30-45\%); hemicellulose (20-30\%); and lignin $(5-20 \%)$. The heterogeneous structure and com- position of the hemicellulose are key impediments to its depolymerization and subsequent utilization in fermentation processes (Barr et al., 2012).

Xylan, a major component of hemicellulose, is a highly branched $\beta$-1,4-linked D-xylose polymer with substituents that include acetyl, arabinosyl, and the glucuronyl groups. The complete degradation of xylan requires the action of several types of enzymes: endo- $\beta-1,4$-xylanase, $\beta$-xylosidase, $\alpha$-arabinofuranosidase, $\alpha$-glucuronidase, acetylxylan esterase, and ferulic acid esterase (Kim and Yoon, 2010). $\beta$-D-Xylosidases ( $\beta$-D-xyloside xylohydrolase; EC 3.2.1.37) hydrolyze short xylooligosaccharides 
and xylobiose from the non-reducing end to liberate xylose. True $\beta$-xylosidases are able to cleave artificial substrates like $p$-nitrophenyl- $\beta$-D-xyloside. These enzymes appear to be mainly cell associated in bacteria and yeasts. However, extracellular xylosidase activities have also been reported (Knob et al., 2010).

Arabinan is one the most important primary cell wall components of different families of plants in seeds, fruits, and roots. This polysaccharide is associated to pectic substances side-chains or as free polymers unattached to pectic domains. Its chemical structure usually consists of $\alpha$-1,5-linked L-arabinofuranosyl units, but variably branched at $O-2$ and/or $O-3$ by single arabinosyl residues. Arabinan is linked to rhamnogalacturonan in the plant cell walls, but it is possible to find some phenolic esters between the rhamnogalacturonan polymers, such as feruloyl or coumaroyl (Damásio et al., 2012; Hara et al., 2013).

There are two types of arabinases, the exo-acting $\alpha$-L-arabinofuranosidase (EC 3.2.1.53), which is active against $p$-nitrophenyl- $\alpha$-L-arabinofuranosides and on branched arabinans, and the endo-1,5- $\alpha$-arabinanase (EC 3.2.1.99), which is active only toward linear arabinans. These enzymes hydrolyze 1,5 - $\alpha$-arabinans, but they are not able to hydrolyze the chromogenic substrate phenyl- $\alpha$-L-arabinofuranoside or gum arabic (Wong et al., 2008).

Many microorganisms including bacteria, yeasts and fungi are known to produce different types of hemicellulases and the nature of the enzymes varies among different organisms. In the case of arabinan-degrade enzymes, little is known about this group, some researchers have been isolating them from different sources, and others have been trying to clone and express these enzymes. It can be reported, for example, the study of Hong et al. (2009), which expressed a thermotolerant recombinant endo1,5- $\alpha$-L-arabinanase from Caldicellulosiruptor saccharolyticus. Other study from Wong et al. (2008), showed a novel exo- $\alpha-1,5-\mathrm{L}$-arabinanase that was cloned and expressed heterologously, the gene was isolated from rumen microbial metagenome. In this case this enzyme did not work at high temperatures, but show exo-activity, which is few reported in the literature. Most of the xylan-degrading enzymes are produced by mesophilic and thermophilic microorganisms, and have been found and studied in bacteria and fungi, and filamentous fungi have been widely used as enzyme producers and generally are considered more potent producers of xylanases than bacteria and yeasts (Polizeli et al., 2005; Pedersen et al., 2007). Among the mesophilic fungi, the commercial production of xylanases is highlighted in the genera Aspergillus and Trichoderma, due to its potential for thermotolerance and production of thermostable enzymes (Pedersen et al., 2007). These enzymes are of interest because the increase of reaction temperature, generally increases the reaction rate and reduces the risks of microbial contamination (Collins et al., 2005).

Most of the microorganisms currently used for ethanol production from lignocellulosic and starchy sugars are mesophiles with optimum of growth and fermentation temperatures varying between $28^{\circ} \mathrm{C}$ and $40{ }^{\circ} \mathrm{C}$ (Voronovsky et al., 2009). Currently, there is a large industrial interest in the isolation and study of thermophile/thermotolerant microorganisms capable of producing thermostable enzymes which are resistant to high temperatures (Ramírez et al., 2012). This is because the enzymes from thermophilic organisms show resistance to extreme physical and chemical conditions, once these enzymes can work efficiently at high temperatures and low $\mathrm{pH}$, characteristics required for the pretreatment of lignocellulose biomasses (Girfoglio et al., 2012).

Some of the fungi analyzed in this study had already been studied in our laboratory for the production of xylanase, as A. phoenicis (Rizzatti et al., 2001); A. caespitosus (Sandrim et al., 2005); A. niveus (Peixoto-Nogueira et al., 2009); A. niger (Betini et al., 2009), A. terricola (Michelin et al., 2012b) and A. ochraceus (Betini et al., 2009), and these were included in the "screening", to be good producers of xylanases. In addition arabinanases and xylosidases are important enzymes that work hydrolyzing backbone and side chain of hemicellulose, they act helping in the process of lignocellulosic material deconstruction. Accordingly, this work aimed to screen important thermophilic/ thermotolerant fungi to study the production of $\beta$-xylosidase and arabinanase.

\section{Materials and Methods}

\section{Microorganisms and maintenance}

The fungi used in this study were collected from several regions of the São Paulo State (Brazil), as established by the SisBiota - FAPESP program. The microorganisms were identified using morphological characteristics by Departamento de Micologia da Universidade Federal de Pernambuco - PE, Brazil, as Aspergillus caespitosus USPRP68, A. thermomutatus anamorph de Neosartorya pseudofischeri USP-RP69, A. ochraceus USP-RP70, $A$. phoenicis USP-RP71, A. terreus USP-RP72, A parasiticus USP-RP73, A. niger USP-RP67, Beauveria brongniartii USP-RP74, Mucor racemosus USP-RP75, Paecilomyces variotii USP-RP76, Penicillium purpurogenum USP-RP77 and A. niger var. awamori USP-RP78. The fungi have been maintained in silica gel or ultrafreezer $-80^{\circ} \mathrm{C}$ at the Filamentous Fungi Collection - CFF of Departamento de Biologia, Faculdade de Filosofia, Ciências e Letras de Ribeirão Preto - Universidade de São Paulo. All fungi were cataloged by Specify software program. On the other hand, the microorganisms were also maintained routinely on solid $4 \%$ oatmeal baby food (Quaker) medium or in Vogel com- 
plete solid medium (Vogel, 1964) with 2\% glucose as the carbon source.

\section{Screening of thermotolerant and thermophilic microorganisms on solid medium}

The screening was carried out in Petri dishes containing complete solid medium modified from Selig et al. (2008): (total volume of $100 \mathrm{~mL}$ of solid medium: $5 \mathrm{~mL}$ of salts $\left(0.6 \mathrm{~g} \mathrm{NaNO}_{3}\right.$, Sigma S5506; $0.052 \mathrm{~g} \mathrm{KCl}$, Sigma 746436; $0.052 \mathrm{~g} \mathrm{MgSO}_{4}$, Sigma M7506; $0.152 \mathrm{~g} \mathrm{KH}_{2} \mathrm{PO}_{4}$, Sigma P9791); $0.1 \mathrm{~mL}$ of salt minimal solutions $(0.0022 \mathrm{~g}$ $\mathrm{ZnSO}_{4}$, Sigma 96495; $0.0011 \mathrm{~g} \mathrm{H}_{3} \mathrm{BO}_{3}$, Sigma B6768; $0.0005 \mathrm{~g} \mathrm{MnCl}_{2}$, Sigma 244589; $0.0005 \mathrm{~g} \mathrm{FeSO}_{4}$, Sigma 12353; $0.00016 \mathrm{~g} \mathrm{CoCl}_{2}$, Sigma 60818; $0.00016 \mathrm{~g} \mathrm{CuSO}_{4}$, Sigma 61230; $0.00011 \mathrm{~g} \mathrm{Na}_{2} \mathrm{MoO}_{4}$, Sigma 243655; $0.005 \mathrm{~g}$ $\mathrm{Na}_{2}$ EDTA, Sigma E5134); $0.1 \mathrm{~mL}$ of vitamin solution Sigma V1 (0.02 mM nicotinic acid; $0.01 \mathrm{mM}$ pyridoxine- $\mathrm{HCl} ; 0.02 \mathrm{mM}$ thiamine- $\mathrm{HCl} ; 0.02 \mathrm{mM}$-aminobenzoic acid; $0.02 \mathrm{mM}$ panthotenate; $0.05 \mu \mathrm{M}$ folic acid; $0.05 \mu \mathrm{M}$ riboflavin); $1 \%$ glucose, Sigma G8270; 0.5\% peptone, Sigma P0556; 0.5\% yeast extract, Sigma Y1625; 2.5\% agar, Sigma A5306 and distilled water), $\mathrm{pH} 6.5$. Punctual inoculums was carried out at the center of the solid medium (using sticks autoclaved), and the plates with the culture medium were maintained at different temperatures, $30{ }^{\circ} \mathrm{C}-50{ }^{\circ} \mathrm{C}$, with intervals of $5^{\circ} \mathrm{C}$ among them, in a bacteriological incubator. The halo fungi were measured after 24 and $48 \mathrm{~h}$ of grown.

\section{Obtainment of $\beta$-xylosidase and $\alpha$-arabinanase from isolate fungi}

$\beta$-xylosidase and $\alpha$-arabinanase were obtained when the fungi were growth in Czapek liquid culture medium (Wiseman, 1975), pH 6.0, supplemented with 1\% wheat fiber. Then, they were incubated under static conditions (without agitation) for five days, the temperature ranged from $30{ }^{\circ} \mathrm{C}$ to $45^{\circ} \mathrm{C}$, with intervals of $5^{\circ} \mathrm{C}$. Afterwards, the cultures were harvested by filtration on Whatman $n^{\circ} 1$ paper and the filtrates were used as source of crude extracellular activity. The mycelia pads obtained were ground in a mortar with 2 volumes of glass beads, at $0{ }^{\circ} \mathrm{C}$, and extracted with sodium acetate buffer $100 \mathrm{mM}$, pH 5.0. The slurry was centrifuged at $12,000 \mathrm{xg}$ for $15 \mathrm{~min}$, at $4{ }^{\circ} \mathrm{C}$. The supernatant was the source of crude intracellular enzyme.

\section{Enzymatic assays and protein determination}

The quantification of $\beta$-xylosidase and arabinanase activities were performed using the method described by Kersters-Hilderson et al. (1982) and by Miller (1959), respectively. For the first method it was used 1\%p-nitrophenyl- $\beta$-D-xylopyranoside ( $p$ NP-xyl, Sigma N2132) in $100 \mathrm{mM}$ sodium succinate, $\mathrm{pH} 5.0$ as substrate. The reaction mixture was incubated at $60{ }^{\circ} \mathrm{C}$, for $5 \mathrm{~min}$, and the $p$-nitrophenol), formed was quantified by spectrophoto- metry at $405 \mathrm{~nm}$. The method was previously standardized by a curve of $p$-nitrophenol (PNP, Sigma 1041) (0.09 to $0.54 \mu \mathrm{mols})$. The activity unit was defined as the amount of enzyme capable of liberating $1 \mu \mathrm{mol}$ of $p$-nitrophenol $/ \mathrm{min} / \mathrm{mL}$. In order to determine the arabinanase activity the assay was carried out at $60{ }^{\circ} \mathrm{C}$ with a mixture containing $250 \mu \mathrm{L}$ of a solution of $1 \%$ debranched arabinan, Megazyme P-DBAR, in $100 \mathrm{mM}$ sodium succinate, Sigma 14160, pH 5.0, and $250 \mu \mathrm{L}$ of diluted enzyme. Aliquots $(100 \mu \mathrm{L})$ were withdrawn after different time intervals (15 and $30 \mathrm{~min}$ ), and the assay tubes covered with parafilm and boiled for $5 \mathrm{~min}$. The tubes were then chilled and $1 \mathrm{~mL}$ of distilled water was added. The blanks consisted of $100 \mu \mathrm{L}$ of reaction mixture with the immediate addition of $100 \mu \mathrm{L}$ of DNS. The control was performed by incubating the substrates in $100 \mathrm{mM}$ sodium succinate, $\mathrm{pH}$ 5.0 , for $30 \mathrm{~min}$ at $60^{\circ} \mathrm{C}$, and the reducing sugars were detected. The absorbance readings were made at $540 \mathrm{~nm}$ using a microplate. Arabinose, Sigma A3256, was used as the standard ( 0.1 to $\left.1.0 \mathrm{mg} \cdot \mathrm{mL}^{-1}\right)$, and the activity unit (U) was defined as the amount of enzyme capable of liberating $1 \mu \mathrm{mol}$ of reducing sugar formed per minute per $\mathrm{mL}$, under the assay conditions. Protein was determined at $595 \mathrm{~nm}$ according to Bradford (1976), using bovine serum albumin, Sigma 05470 , as standard. The unit was defined as mg protein/mL intra or extracellular sample.

\section{Reproducibility of results}

All results are the average of at least three $(n=3)$ independent experiments. The standard deviation for the arabinose curve was $0.0031, \mathrm{p}<0.0001$, and for the p-nitrophenol curve was $0.02808, \mathrm{p}<0.0001$.

\section{Results and discussion}

\section{Analysis of the morphological characteristics of filamentous fungi}

Aiming to select good fungi producers that degrade plant cell wall, twelve microorganisms were obtained from our fungi collection and analyzed in relation to their morphological characters (Figure 1). Our observations confirmed the genera of the fungi previously identified, as described in Methods.

\section{Effect of the temperature on the grown of the isolated fungi}

Thermostable enzymes are of interest because elevation of the reaction temperature (up to a certain limit) generally increases the reaction rate and reduces the risk of microbial contamination (Collins et al., 2005). Among the twelve species examined most of them (Aspergilli and Paecilomyces) achieved maximum growth at $35^{\circ} \mathrm{C}$. Furthermore, it was found that nine species grew at $45^{\circ} \mathrm{C}$, and A. thermomutatus anamorph of Neosartorya 


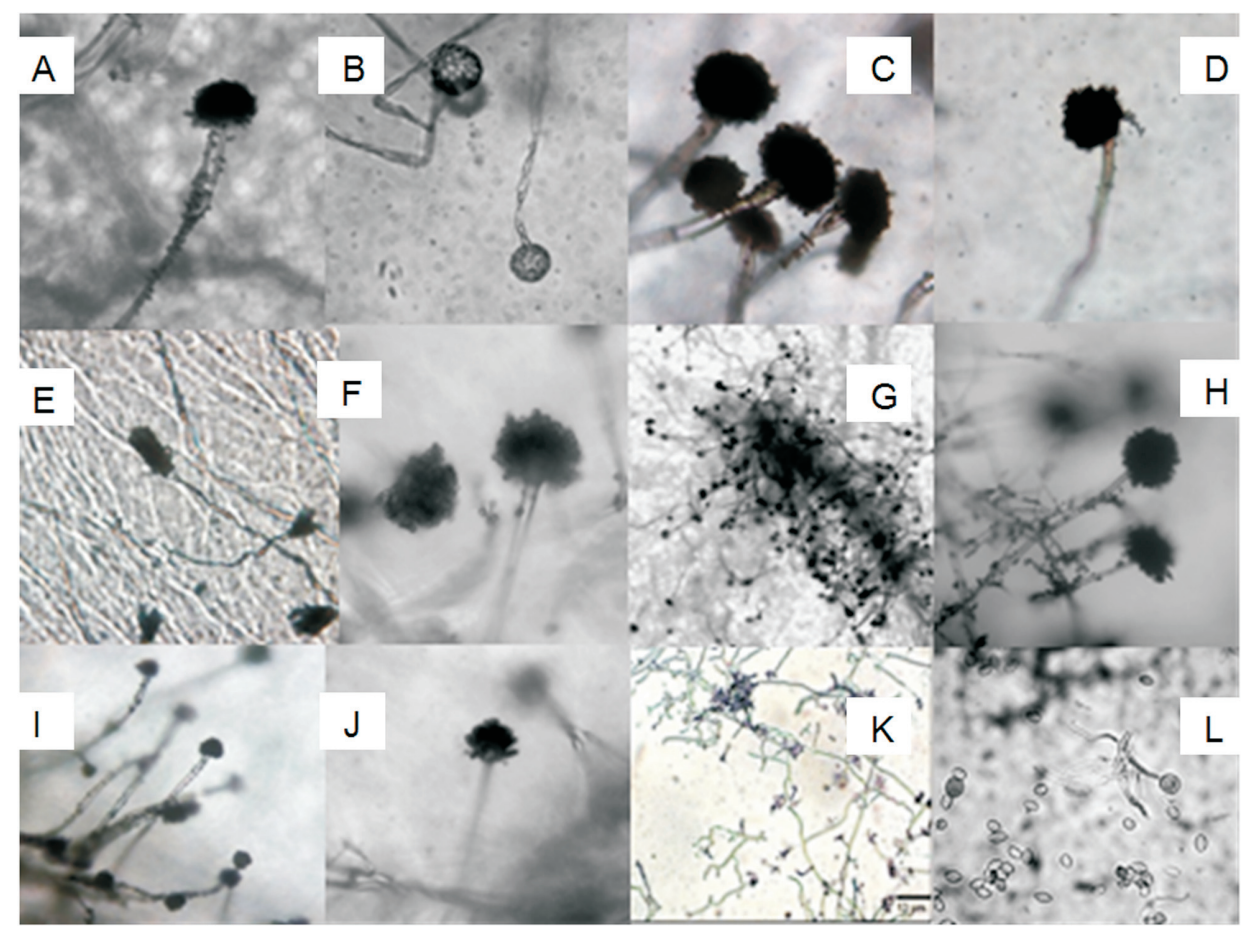

Figure 1 - Microscopic morphology obtained from Light Microscopy of filamentous fungi, 400x. A- A. niger var. awamori; B- M. racemosus; C- A niger; D-A. caespitosus; E- P. purpurogenum; F-A. parasiticus; G- A. thermomutatus; H- A. terreus; I- A. phoenicis; J-A. ochraceus; K- B. brongniartii; L- P. variotii.

pseudofischeri reached its maximum development at $40{ }^{\circ} \mathrm{C}-45^{\circ} \mathrm{C}$, having a $4.0 \mathrm{~cm}$ halo after $48 \mathrm{~h}$, featuring an increase of approximately $0.083 \mathrm{~cm} / \mathrm{h}$. It could be observed that $A$. thermomutatus as well as $A$. parasiticus were the only fungi that grew at $50{ }^{\circ} \mathrm{C}$, with a mycelial halo of $0.5 \mathrm{~cm}$ after $48 \mathrm{~h}$ (Table 1). B. brongniartii and $M$. racemosus had better growth at $30^{\circ} \mathrm{C}$, on the other hand, $P$. purpurogenum showed optimum growth at both temperatures $\left(30^{\circ} \mathrm{C}-35^{\circ} \mathrm{C}\right)$. Then, these three fungi showed mesophilic character compared to the Aspergilli species studied. These results corroborate the reports of Pedersen et al. (2007), where it was verified that among the termophilic fungi, the commercial production of xylanases is highlighted in the genera Aspergillus and Trichoderma, due to its potential thermotolerance and production of thermostable enzymes.

\section{Screening of $\beta$-xylosidase produced by filamentous fungi}

Enzymes produced by microorganisms are excellent for industrial use, once that the production is fast; lower production costs; possibility of large-scale production in industrial fermentors; wide range of physical and chemical characteristics; possibility of genetic manipulation; it is seasonal independent; etc. However, the preference is given to the extracellular form, i.e., secreted from the culture medium due to the ease of enzyme extraction. These characteristics are typical of filamentous fungi, but the same is not observed for bacteria and yeasts (Polizeli et al.,
2005). In this context, the production of extra and intracellular $\beta$-xylosidases, and arabinanase from various fungi was analyzed correlating them with the growth temperature (Figure 2).

The extracellular activity was higher to $A$. niger, $A$. phoenicis, $P$. variotii, A. ochraceus, A. niger var. awamori (about $0.723 \mathrm{U} / \mathrm{mL}$, Figure 2A), when the fungi were cultivated at $30^{\circ} \mathrm{C}$. However, the activity decreased about $31 \%$ (compared to the temperature of $30{ }^{\circ} \mathrm{C}$ - average of $0.223 \mathrm{U} / \mathrm{mL}$ ) when the microorganisms were cultivated at higher temperature $\left(35-40{ }^{\circ} \mathrm{C}\right.$, Figures $\left.2 \mathrm{~B}, \mathrm{C}\right)$, and at $45^{\circ} \mathrm{C}$ this activity was reduced to very low levels (Figure 2D).

The intracellular $\beta$-xylosidase activity was higher in cultures at $30{ }^{\circ} \mathrm{C}$, for the same microorganisms mentioned above $(0.279 \mathrm{U} / \mathrm{mL}$ average levels, Figure $2 \mathrm{~A})$. Nevertheless, this activity reduced approximately $50 \%$ at 35 ${ }^{\circ} \mathrm{C}-40{ }^{\circ} \mathrm{C}$ and $77 \%$ at $45^{\circ} \mathrm{C}$ (about 0.065 ). The fungi growth was accompanied by decreased activity (Table 2), but a drastic reduction was not observed. Then, by the correlation of activity/mycelial protein (specific activity) it was possible to suggest that the temperature of $45^{\circ} \mathrm{C}$ did not favor the cell machinery to enzyme synthesis. On the other hand, it was observed that the intracellular enzyme levels were higher at $35{ }^{\circ} \mathrm{C}$ for Aspergillus thermomutatus followed by A. caespitosus, A. parasiticus, A. terreus, M. racemosus and $P$. purpurogenum $(0.136 \mathrm{U} / \mathrm{mL}$ average activity levels, Figure 3B) compared at $30^{\circ} \mathrm{C}$ and at $40^{\circ} \mathrm{C}$.

At $45{ }^{\circ} \mathrm{C}$ insignificant levels of intracellular activity were detected. In relation to the protein levels, it was veri- 
Table 1 - Radius length of the mycelia halo analyzed of fungi culture.

\begin{tabular}{|c|c|c|c|c|c|}
\hline \multirow[t]{2}{*}{ Fungi } & \multicolumn{5}{|c|}{ Radius of the mycelial halo $(\mathrm{cm})-48 \mathrm{~h}$} \\
\hline & $30{ }^{\circ} \mathrm{C}$ & $35^{\circ} \mathrm{C}$ & $40{ }^{\circ} \mathrm{C}$ & $45^{\circ} \mathrm{C}$ & $50{ }^{\circ} \mathrm{C}$ \\
\hline Aspergillus caespitosus & $2.3 \pm 0.017$ & $3.0 \pm 0.015$ & $2.2 \pm 0.014$ & $1.5 \pm 0.012$ & n.g. \\
\hline Aspergillus niger var. awamori & $2.7 \pm 0.015$ & $3.2 \pm 0.014$ & $2.0 \pm 0.015$ & $1.0 \pm 0.014$ & n.g. \\
\hline Aspergillus thermomutatus & $1.7 \pm 0.014$ & $3.5 \pm 0.016$ & $3.5 \pm 0.017$ & $4.0 \pm 0.017$ & $0.5 \pm 0.015$ \\
\hline Aspergillus ochraceus & $1.8 \pm 0.017$ & $2.2 \pm 0.016$ & $1.6 \pm 0.015$ & $1.0 \pm 0.014$ & n.g. \\
\hline Aspergillus phoenicis & $3.7 \pm 0.016$ & $3.5 \pm 0.017$ & $2.0 \pm 0.017$ & $1.3 \pm 0.017$ & n.g. \\
\hline Aspergillus terreus & $2.0 \pm 0.020$ & $2.7 \pm 0.019$ & $2.2 \pm 0.015$ & $1.8 \pm 0.014$ & n.g. \\
\hline Aspergillus parasiticus & $2.8 \pm 0.015$ & $3.0 \pm 0.015$ & $1.6 \pm 0.016$ & $0.9 \pm 0.009$ & $0.5 \pm 0.016$ \\
\hline Aspergillus niger & $2.0 \pm 0.015$ & $3.0 \pm 0.020$ & $1.0 \pm 0.010$ & $0.8 \pm 0.016$ & n.g. \\
\hline Beauveria brongniartii & $1.2 \pm 0.018$ & $0.5 \pm 0.010$ & n.g. & n.g. & n.g. \\
\hline Mucor racemosus & $5.0 \pm 0.020$ & $4.0 \pm 0.014$ & $1.0 \pm 0.017$ & n.g. & n.g. \\
\hline Paecilomyces variotii & $1.7 \pm 0.017$ & $2.5 \pm 0.017$ & $1.5 \pm 0.014$ & $0.8 \pm 0.017$ & n.g. \\
\hline Penicillium purpurogenum & $0.8 \pm 0.012$ & $0.8 \pm 0.011$ & $0.3 \pm 0.009$ & n.g. & n.g. \\
\hline
\end{tabular}

n.g. - the fungi did not grow.
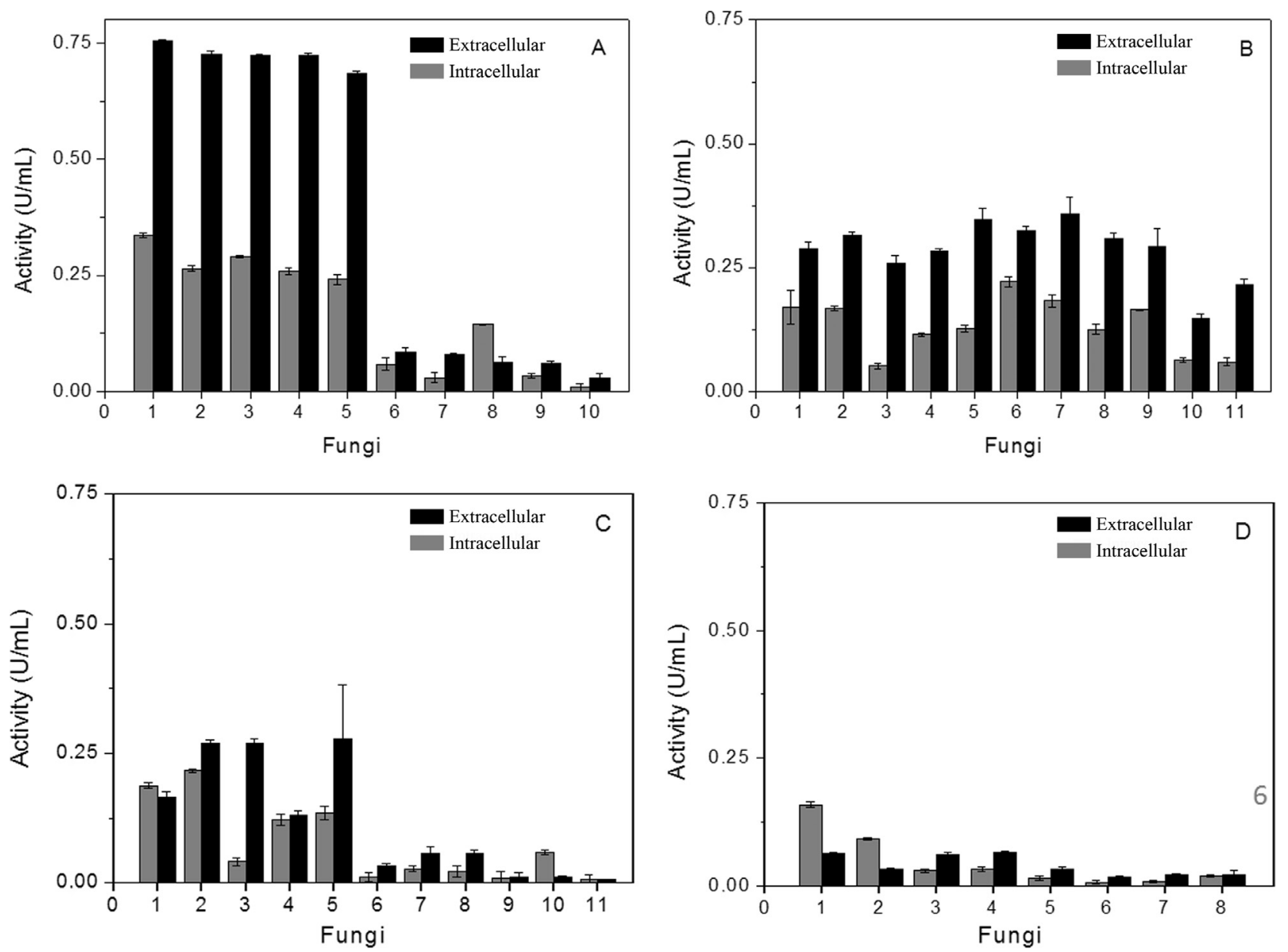

Figure 2 - Analysis of intracellular and extracellular $\beta$-xylosidase activities produced by fungi grown at different temperatures: $(\mathrm{A}) 30{ }^{\circ} \mathrm{C},(\mathrm{B}) 35^{\circ} \mathrm{C},(\mathrm{C})$ $40{ }^{\circ} \mathrm{C}$ and (D) $45^{\circ} \mathrm{C}$. Fungi: 1- A. niger, 2- A. phoenicis, 3- P. variotii, 4- A. ochraceus, 5- A. niger var. awamori, 6- $A$. thermomutatus, 7- $A$. caespitosus, 8-A. terreus, 9-A. parasiticus, 10-M. racemosus, 11-P. purpurogenum, 12- B. brongniartii. 
Table 2 - The amount of protein produced by various microorganisms.

\begin{tabular}{|c|c|c|c|c|c|c|c|c|}
\hline & \multicolumn{8}{|c|}{ Protein $(\mathrm{mg} / \mathrm{mL})$} \\
\hline & \multicolumn{4}{|c|}{ Intracellular } & \multicolumn{4}{|c|}{ Extracellular } \\
\hline & $30^{\circ} \mathrm{C}$ & $35^{\circ} \mathrm{C}$ & $40{ }^{\circ} \mathrm{C}$ & $45^{\circ} \mathrm{C}$ & $30^{\circ} \mathrm{C}$ & $35^{\circ} \mathrm{C}$ & $40^{\circ} \mathrm{C}$ & $45^{\circ} \mathrm{C}$ \\
\hline A. niger & 0.142 & 0.171 & 0.156 & 0.138 & 0.256 & 0.289 & 0.275 & 0.116 \\
\hline A. phoenicis & 0.170 & 0.168 & 0.155 & 0.132 & 0.262 & 0.315 & 0.294 & 0.152 \\
\hline P. variotii & 0.031 & 0.022 & 0.038 & 0.023 & 0.300 & 0.259 & 0.237 & 0.171 \\
\hline A. ochraceus & 0.103 & 0.095 & 0.106 & 0.075 & 0.307 & 0.284 & 0.203 & 0.125 \\
\hline A. niger var. awamori & 0.105 & 0.127 & 0.111 & 0.089 & 0.300 & 0.346 & 0.207 & 0.115 \\
\hline A. thermomutatus & 0.122 & 0.135 & 0.188 & 0.192 & 0.289 & 0.335 & 0.247 & 0.197 \\
\hline A. caespitosus & 0.157 & 0.183 & 0.146 & 0.133 & 0.256 & 0.359 & 0.103 & 0.089 \\
\hline A. terreus & 0.086 & 0.125 & 0.120 & 0.056 & 0.310 & 0.308 & 0.155 & 0.049 \\
\hline A. parasiticus & 0.168 & 0.175 & 0.131 & 0.115 & 0.326 & 0.293 & 0.123 & n.g. \\
\hline M. racemosus & 0.074 & 0.093 & 0.047 & n.g. & 0.320 & 0.148 & 0.100 & n.g. \\
\hline P. purpurogenum & 0.061 & 0.060 & 0.037 & n.g. & 0.152 & 0.215 & 0.156 & n.g. \\
\hline B. brongniartii & 0.113 & 0.099 & n.g. & n.g. & 0.235 & 0.118 & n.g. & n.g. \\
\hline
\end{tabular}

n.g. - the fungi did not grow.

Standard deviation: 0.004 .
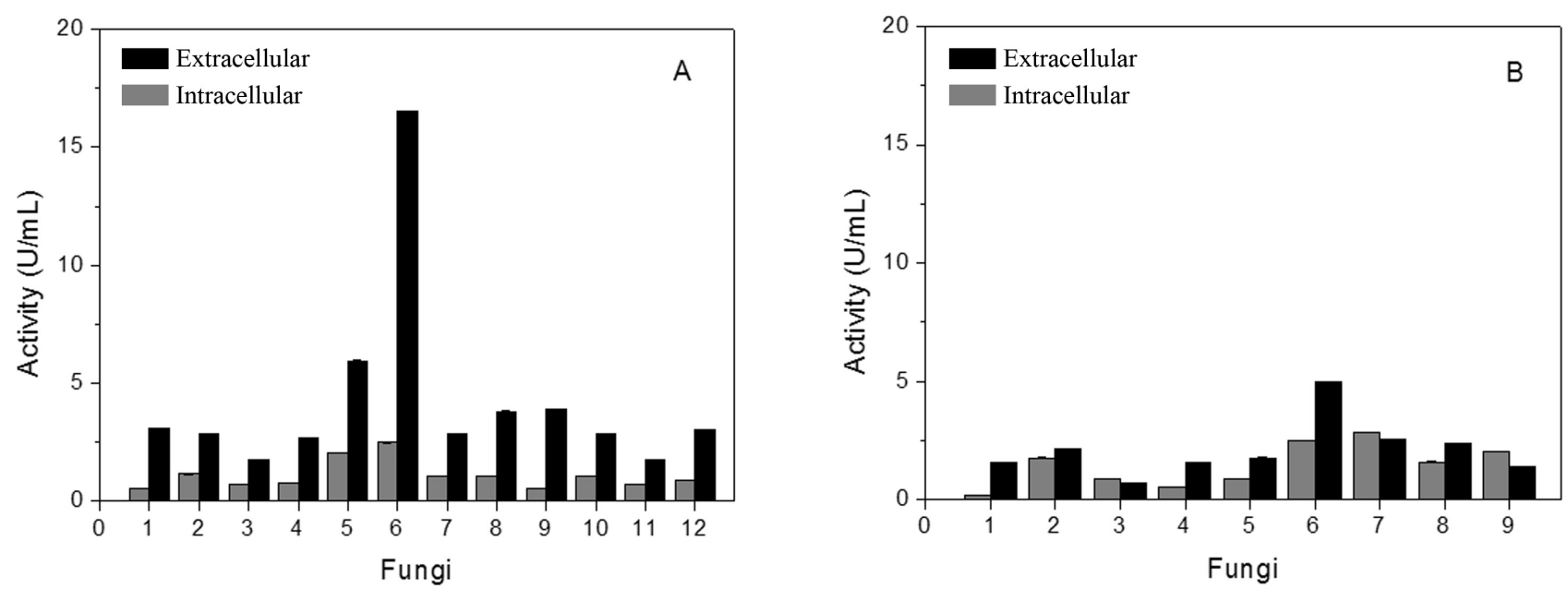

Figure 3 - Intracellular and extracellular arabinanase activities produced by fungi grown at different temperatures: (A) $30{ }^{\circ} \mathrm{C}$ and $(\mathrm{B}) 40{ }^{\circ} \mathrm{C}$. The microorganisms were cultured on Czapek medium, initial pH 6.0, supplemented with $1 \%$ wheat fiber under static condition, during five days. Fungi: $1-A$. niger, 2- A. phoenicis, 3- P. variotii, 4- A. ochraceus, 5- A. niger var. awamori, 6- A. thermomutatus, 7- A. caespitosus, 8- A. terreus, 9- A. parasiticus, 10- M. racemosus, 11- P. purpurogenum, 12-B. brongniartii.

fied that there was not considerable variation as previously detected to the other Aspergilli cited (Table 2). The filamentous fungus $B$. brongniartii that grew at temperatures of $30^{\circ} \mathrm{C}$ and $35^{\circ} \mathrm{C}$ (Table 2, average $0.106 \mathrm{mg}$ of mycelia protein $/ \mathrm{mL}$ ) but did not produce $\beta$-xylosidase in any of the studied temperatures. From the biotechnological point of view, this obtained data are interesting since there are few reports on extracellular $\beta$-xylosidases and their action mechanism on xylooligosaccharides.

Some studies in the literature consist of $\beta$-xylosidase secretion (Kiss and Kiss, 2000; Rizzatti et al., 2001; Saha, 2001; Lenartovicz et al., 2003; Guerfali et al., 2008; Yan et al., 2008; Michelin et al., 2012a and 2012b), but others have demonstrated that $\beta$-xylosidases remain associated to the mycelium (Kumar and Ramón, 1996; Ito et al., 2003; Katapodis et al., 2006; Lembo et al., 2006; Ohta et al., 2010). The induction of the xylanolytic enzymes initially occurs by the physical contact between cell and the inducer source; which suggests the existence of some recognition site on the cell surface. Constitutive xylanases are supposed to be responsible for the initial hydrolysis of xylan, producing small $\beta$-D-xylopyranosyl oligosaccharides such as xylobiose and xylotriose. $\beta$-Xyloside permeases mediate the transport of these oligosaccharides into the cell, where 
they trigger the expression of the xylanolytic system genes. So, $\beta$-xylosidases are expressed to hydrolyze xylooligocchacarides to xylose (Polizeli et al., 2005) and they are mostly expressed at the intracellular level and not secreted to the external environment.

\section{Identification of filamentous fungi good producers of arabinanase}

The arabinanase activity was studied at $30{ }^{\circ} \mathrm{C}$ and $40{ }^{\circ} \mathrm{C}$. It was verified that the filamentous fungus $A$. thermomutatus exhibited the best extracellular arabinanase activity at $30{ }^{\circ} \mathrm{C}$ compared to other fungi. Some studies have demonstrated arabinanase activities higher than our findings, with temperatures ranging from $35^{\circ} \mathrm{C}$ to $75^{\circ} \mathrm{C}$ (Hong et al., 2009; Squina et al., 2010; Seo et al., 2010; Inacio and de Sá-Nogueira, 2008). Furthermore, the highest enzymatic activity on debranched arabinan found in this study was similar to that found by Hong et al. (2009), but it was much lower compared to other studies (Wong et al., 2008; Skjøt et al., 2001).

These enzymatic levels were 2.75 -fold higher in relation to A. niger var. awamori, the second best producer. It was verified in these two microorganisms that there was a predominance of extracellular forms $(85 \%$ and $66 \%$, respectively). As far as we know, these two fungi have not been used for the arabinanase production, which makes them strong candidates for the industrial production of this enzyme.

Indeed, most of the fungi cultivated at $40{ }^{\circ} \mathrm{C}$ diminished the extracellular arabinanase activity, but, in contrast, the intracellular activity was higher in cultures at $40{ }^{\circ} \mathrm{C}$ for most microorganisms tested constituting a rate of $50 \%$ for extracellular activity/intracellular activity (Figure 3). An interesting data correlating arabinanase synthesis and fungi growth temperature was the fact that at $40{ }^{\circ} \mathrm{C}$ the intracellular levels produced by $A$. phoenicis, P. variotti, A. caespitosus and $A$. parasiticus were close, similar or slightly higher than the extracellular activity. Then, it is possible to conclude that the fungi growth temperature affects the arabinanase secretion, but how this process occurs is obscure and the elucidation of this phenomenon deserves further investigation.

Studies on hemicellulases have advanced, mainly due to industrial interests, but unlike the majority of components of the arabinases group, arabinanases and arabinofuranosidases, are related enzymes whose action mechanisms are being unveiled in recent years. But the great importance of these enzymes as an important player of the plant cell wall deconstruction mechanism makes this research a valuable screening for the identification of fungal species in Brazil with the potential to produce ancillary hemicellulases (Takao et al., 2002; Hong et al., 2009).

\section{Conclusion}

With these results it is possible to conclude that of twenty Brazilian fungal species analyzed of large mycology collection library, the most proved to developed at temperatures around $30{ }^{\circ} \mathrm{C}-35^{\circ} \mathrm{C}$, however two microorganism grown at $50{ }^{\circ} \mathrm{C}$, as the results demonstrated that specific species of fungi are promising for production of hemicellulases ( $\beta$-xylosidases and arabinanase), that have an important role in the cell wall deconstruction and thus have a promising biotechnological potential.

\section{Acknowledgments}

This work received financial support from Fundação de Amparo à Pesquisa do Estado de São Paulo (FAPESP) and Conselho de Desenvolvimento Científico e Tecnológico (CNPq) - INCT and National System for Research on Biodiversity (Sisbiota-Brazil, $\mathrm{CNPq}$ 563260/2010-6/FAPESP n ${ }^{\circ}$ 2010/52322-3). J. A. Jorge and M.L.T.M. Polizeli are CNPq research fellowship. This work is part of the thesis of Vivian Machado Benassi (VM Benassi, FAPESP) and Rosymar Coutinho de Lucas (Lucas, RC, CNPq) from the Biochemistry Post Graduation Program of FMRP-USP, and both authors contributed equally to this research and manuscript. We thank Ricardo Alarcon and Mauricio de Oliveira for the technical assistance, and also Mariana Cereia for the critical reading of the English manuscript.

\section{References}

Barr CJ, Mertens JA, Schall CA (2012) Critical cellulase and hemicellulase activities for hydrolysis of ionic liquid pretreated biomass. Bioresour Technol 104:480-485.

Betini JHA, Michelin M, Peixoto-Nogueira SC, Jorge JA, Terenzi HF, Polizeli, MLTM (2009) Xylanases from Aspergillus niger, Aspergillus niveus and Aspergillus ochraceus produced by solid state fermentation and its application on cellulose pulp bleaching. Bioprocess Biosystems Eng 32(6):819-824.

Bradford MM (1976) A rapid and sensitive for the quantitation of microgram quantitites of protein utilizing the principle of protein-dye binding. Anal Biochem 72:248-254.

Chapla D, Pandit P, Shah A. (2012) Production of xylooligosaccharides from corncob xylan by fungal xylanase and their utilization by probiotics. Bioresour Technol 115:215-221.

Collins T, Gerday C, Feller G (2005) Xylanases, xylanase families and extremophilic xylanases. FEMS Microbiol Rev 29:3-23.

Damásio ARL, Pessela, BC, Mateo C, Segato F, Prade RA, Guisan JM, Polizeli, MLTM (2012) Immobilization of a recombinant endo-1,5-arabinanase secreted by Aspergillus nidulans strain A773. J Mol Catal B-Enzym 77:39-45.

Girfoglio M, Rossi M, Cannio R (2012) Cellulose degradation by Sulfolobus solfataricus requires a cell-anchored endo- $\beta-1-$ 4-glucanase. J Bacteriol 194(18):5091-5100.

Guerfali M, Gargouri A, Belghith H (2008) Talaromyces thermophilus $\beta$-D-xylosidase: purification, characterization and 
xylobiose synthesis. Appl Biochem Biotechnol 150:267-279 .

Hong MR, Park CS, Oh DK (2009) Characterization of a thermostable endo-1,5- $\alpha$-L-arabinanase from Caldicellulosiruptor saccharolyticus. Biotechnol Lett 31:1439-1443.

Inacio JM, de Sá-Nogueira I (2008) Characterization of abn2 (yxiA), encoding a Bacillus subtilis GH43 arabinanase, Abn2, and its role in arabino-polysaccharide degradation. J Bacteriol 190:4272-4280.

Ito T, Yokoyama E, Sato H, Ujita M, Funaguma T, Furukawa, K, Hara A (2003) Xylosidases associated with the cell surface of Penicillium herquei IFO4674. J Biosci Bioeng 96:354359.

Katapodis, P.; Nerinckx, W.; Claeyssens, M.; Christakopoulos, P. (2006). Purification and characterization of a thermostable intracellular $\beta$-xylosidase from the thermophilic fungus Sporotrichum thermophile. Process Biochem., 41, 2402-2409.

Kersters-Hilderson H, Claeyssens M, Doorslaer EV, Saman E, Bruyne CK (1982) $\beta$-D-Xylosidase from Bacillus pumilus. Methods Enzymol 83:631-639.

Kim YA, Yoon kH (2010) Characterization of a Paenibacillus woosongensis $\beta$-xylosidase $/ \alpha$-arabinofuranosidase produced by recombinant Escherichia coli. J Microbiol Biotechnol 20:1711-1716.

Kiss T, Kiss L (2000) Purification and characterization of an extracellular $\beta$-D-xylosidase from Aspergillus carbonarius. World J Microbiol Biotechnol 16:465-470.

Knob A, Terrasan CRF, Carmona EC (2010) $\beta$-Xylosidases from filamentous fungi: an overview. World J Microbiol Biotechnol 26:389-407.

Kumar S, Ramón D (1996) Purification and regulation of the synthesis of a $\beta$-xylosidase from Aspergillus nidulans. FEMS Microbiol Lett 135:287-293.

Hara Y, Mizukawa H, Yamamoto H, Ikami T, Kato K, Yabe T (2013) Simple Method for refining arabinan polysaccharides by alcohol extraction of the prune, Prunus domestica L. Biosci Biotechnol Biochem 77(10):2137-2139.

Lembo T, Azevedo MO, Bloch C Jr, Filho EXF (2006) Purification and partial characterization of a new $\beta$-xylosidase from Humicola grisea var. thermoidea. World J Microbiol Biotechnol 22:475-479.

Lenartovicz V, De Souza CGM, Moreira FG, Peralta RM (2003) Temperature and carbon source affect the production and secretion of thermostable $\beta$-xylosidase by Aspergillus fumigatus. Process Biochem 38:1775-1780.

Michelin M, Peixoto-Nogueira SC, Silva TM, Jorge JA, Terenzi HF, Teixeira JA, Polizeli MLTM (2012a) A novel xylan degrading $\beta$-D-xylosidase: purification and biochemical characterization. World J Microbiol Biotechnol 28:3179-86.

Michelin M, Polizeli MLTM, Ruzene DS, Silva DP, Ruiz HA, Vicente AA, Jorge, JA, Terenzi HF, Teixeira JA (2012b) Production of xylanase and $\beta$-xylosidase from autohydrolysis liquor of corncob using two fungal strains. Bioprocess Biosyst Eng 35:1185-92.

Miller GL (1959) Use of dinitrosalicylic acid reagent for determination of reducing sugar. Anal Chem 31:426-428.

Ohta K, Fujimoto H, Fujii S, Wakiyama M (2010) Cell-associated $\beta$-xylosidase from Aureobasidium pullulans ATCC20524:
Purification, properties, and characterization of the encoding gene. J Biosci Bioeng 110:152-157.

Pedersen M, Lauritzen HK, Frisvad JC, Meyer AS (2007) Identification of thermostable $\beta$-xylosidase activities produced by Aspergillus brasiliensis and Aspergillus niger. Biotechnol Lett 29:743-748.

Peixoto-Nogueira SC, Michelin M, Betini JHA, Jorge JA, Terenzi HF, Polizeli MLTM (2009) Production of xylanase by Aspergilli using alternative carbon sources: application of the crude extract on cellulose pulp biobleaching. J. Ind. Microbiol. Biotechnol 36(1):149-155.

Polizeli MLTM, Rizzatti ACS, Monti R, Terenzi HF, Jorge JA, Amorim DS (2005) Xylanases from fungi: properties and industrial applications - Review. Appl Microbiol Biotechnol 67:577-591.

Ramírez MGC, Rivera-Ríos JM, Téllez-Jurado A, Gálvez APM, Mercado-Flores Y, Arana-Cuenca A (2012) Screening for thermotolerant Ligninolytic fungi with laccase, lipase, and protease activity isolated in Mexico. J Environ Manage 95:256-259.

Ravanal MC, Callegari E, Eyzaguirre J (2010) Novel bifunctional $\alpha$-L-arabinofuranosidase/xylobiohydrolase (ABF3) from Penicillium purpurogenum. Appl Environ Microbiol 76:5247-5253.

Rizzatti ACS, Jorge JA, Terenzi HF, Rechia CGV, Polizeli MLTM (2001) Purification and properties of a thermostable extracellular $\alpha$-D-xylosidase produced by thermotolerant Aspergillus phoenicis. J Ind Microbiol Biotechnol 26:156160.

Saha BC (2001) Purification and characterization of an extracellular $\beta$-xylosidase from a newly isolated Fusarium verticillioides. J Ind Microbiol Biotechnol 27:241-245.

Sandrim VC, Rizzatti ACS, Terenzi HF, Jorge JA, Milagres AMF, Polizeli MLTM (2005) Purification and biochemical characterization of two xylanases produced by Aspergillus caespitosus and their potential for kraft pulp bleaching. Process Biochem 40:1823-1828.

Selig MJ, Knoshaug EP, Decker SR, Baker JO, Himmel ME, Adney WS (2008) Heterologous expression of Aspergillus niger beta-D-xylosidase $(\mathrm{X} \ln \mathrm{D})$ : characterization on lignocellulosic substrates. Appl Biochem Biotechnol 146:57-68.

Seo E-S, Lim Y-R, Kim Y-S, Park C-S, Oh D-K (2010) Characterization of a recombinant endo-1,5- $\alpha-1$-arabinanase from the isolated bacterium Bacillus licheniformis. Biotechnol. Bioprocess Eng 15:590-594.

Skjøt M, Kauppinen S, Kofod LV, Fuglsang C, Pauly M, Dalbøge H, Andersen LN (2001) Functional cloning of an endoarabinanase from Aspergillus aculeatus and its heterologous expression in $A$. or oryzae and tobacco. Mol Genet Genomics 265(5):913-21.

Squina FM, Santos CR, Ribeiro DA, Cota J, de Oliveira RR, Ruller R, Mort A, Murakami MT, Prade RA (2010) Substrate cleavage pattern, biophysical characterization and low-resolution structure of a novel hyperthermostable arabinanase from Thermotoga petrophila. Biochem Biophys Res Commun 399:505-511.

Takao M, Akiyama K, Sakai T (2002) Purification and characterization of thermostable endo-1,5- $\alpha$-L-arabinase from a 
strain of Bacillus thermodenitrificans. Appl Environ Microbiol 68:1639-1646.

Vogel HJ (1964) Distribution of lysine pathways among fungi: evolutionary implications. Am Nat 98:435-446.

Voronovsky AY, Rohulya OV, Abbas CA, Sibirny AA (2009) Development of strains of the thermotolerant yeast Hansenula polymorpha capable of alcoholic fermentation of starch and xylan. Metab Eng 11:234-242.

Wiseman A (1975) Handbook of Enzyme Biotechnology. Ellis Horwood Ltd John Wiley \& Sons. p. 148.
Wong DW, Chan VJ, Batt SB (2008) Cloning and characterization of a novel exo-alpha-1,5-L-arabinanase gene and the enzyme. App Microbiol Biotechnol 79:941-949.

Yan QJ, Wang L, Jiang ZQ, Yang SQ, Zhu HF, Li LT (2008) A xylose-tolerant $\beta$-xylosidase from Paecilomyces thermophila: characterization and its co-action with the endogenous xylanase. Bioresour Technol 99:5402-5410.

All the content of the journal, except where otherwise noted, is licensed under a Creative Commons License CC BY-NC. 